Marquette University

e-Publications@Marquette

Finance Faculty Research and Publications

Finance, Department of

$12-1-2012$

\title{
Going Overboard? On Busy Directors and Firm Value
}

George D. Cashman

Marquette University, george.cashman@marquette.edu

Stuart L. Gillan

University of Georgia - Athens

Chulhee Jun

United International College - Tangjiawan, Zhuhai, Guangdong

Accepted version. Journal of Banking and Finance, Vol. 36, No. 12 (December 2012): 3248-3259.

DOI. (C) 2012 Elsevier B.V. Used with permission.

George D. Cashman was affiliated with Texas Tech University at the time of publication. 
Marquette University

e-Publications@Marquette

\title{
Finance Faculty Research and Publications/College of Business Administration
}

This paper is NOT THE PUBLISHED VERSION; but the author's final, peer-reviewed manuscript. The published version may be accessed by following the link in the citation below.

Journal of Banking \& Finance, Vol. 36, No. 12 (2012): 3248-3259. DOI. This article is (C) Elsevier and permission has been granted for this version to appear in e-Publications@Marquette. Elsevier does not grant permission for this article to be further copied/distributed or hosted elsewhere without the express permission from Elsevier.

\section{Going overboard? On busy directors and firm value}

\author{
George D. Cashman
}

Rawls College of Business, Texas Tech University, Lubbock, TX

Stuart L. Gillan

Terry College of Business, University of Georgia, Athens, GA

Chulhee Jun

Division of Business and Management, United International College, Tangjiawan, Zhuhai

\footnotetext{
Abstract

The literature disagrees on the link between so-called busy boards (where many independent directors hold multiple board seats) and firm performance. Some argue that busyness certifies a director's ability and that such directors are value enhancing. Others argue that "over-boarded" directors are ineffective and detract from firm value. We find evidence that (1) the disparate results in prior work stem from differences in both sample composition and empirical design, (2) on balance the results suggest a negative association between board busyness and firm performance, and (3) the inclusion of firm fixed
} 
effects dramatically affects the conclusions drawn from, and the explanatory power of, multivariate analyses. We also explore alternative empirical definitions of what constitutes a busy director and find that commonly used proxies for busyness perform well relative to more complex alternatives.

Highlights

- The disparate busy director findings result from different samples and methodology. Including firm fixed effects results in a constant negative relation. The common busy director definition is as informative as more intense alternatives.

\section{Keywords}

Corporate governance, Boards of directors, Busy directors

\section{Introduction}

The link between busy directors (independent directors with multiple board appointments) and firm performance is an issue of debate in the literature. Some argue that multiple directorships are a certification of a director's abilities (Fama and Jensen, 1983). Therefore, busy directors should positively affect firm performance. Others argue that busy directors are less effective due to the increased time commitment associated with multiple board appointments. Therefore, the presence of directors with multiple board seats should negatively influence firm performance.

Two of the more recent papers that exemplify this debate are Ferris et al., 2003, Fich and Shivdasani, 2006. Ferris et al. (2003) finds that the past performance of the firms on which a director serves is positively associated with the number of board seats that he hold and that firms appointing a new director with multiple board seats experience positive announcement returns. These results suggest that the market perceives the appointment of an independent director with multiple board seats as value enhancing. In contrast, Fich and Shivdasani (2006) find that firms where directors have multiple board seats tend to have lower market to book ratios and are less likely to fire a CEO in response to poor performance. Furthermore, the announcement of a director accepting his or her third board seat negatively affects the value of other firms where the individual is a board member. Fich and Shivdasani (2006) argue that directors with multiple appointments are busy; therefore, they are less able to effectively monitor and advise management, which adversely affects firm performance. This perspective is echoed by institutional investors proposing "best practices", that would limit the number of board seats a director can hold. Reports further suggest that institutional investors are taking a harder stance against CEOs serving on multiple boards. More generally, time commitments for board members appear to be on the increase, with even one directorship taking an average time commitment of 228 hours in 2011, according to the National Association of Corporate Directors (see Lublin, 2012).

We reexamine the impact of busy directors on firm performance, with emphasis on reconciling the contradictory findings in the literature. In addition to exploring alternate empirical approaches, we investigate whether or not the results are robust to more comprehensive definitions of what constitutes a busy director. Our goal is to reconcile the disparate findings in the literature and provide 
guidance for those examining board structure and busyness from an empirical standpoint. We acknowledge the omnipotent endogeneity concerns in this type of analysis and, while we do explore the direction of causality, our approach is to use representative analyses consistent with prior work in order to focus on the conflicting results. ${ }^{1}$

Using a more recent sample we first revisit the results of Fich and Shivdasani, 2006, Ferris et al., 2003. Focusing on S\&P 500, firms we find evidence of a negative association between busy directors and firm performance, consistent with Fich and Shivdasani's (2006) analysis of the Forbes 500. However, when we examine a broader sample including non-S\&P 500 firms, we find evidence of a positive link between busy directors and firm performance, consistent with Ferris et al. (2003) analysis of more than three thousand COMPUSTAT firms. Our ability to find results consistent with the findings of both Fich and Shivdasani, 2006, Ferris et al., 2003 suggests that the conflicting findings are attributable to differences in the samples studied or other aspects of the empirical design.

With regard to empirical design, Brookman and Thistle, 2011, Coles and Li, 2011, and Graham et al. (2012), highlight the importance of controlling for unobservable firm characteristics. These papers report that controlling for firm fixed effects changes previously documented relations in the CEO compensation literature. Thus, in the spirit of this work, and consistent with the approach of Fich and Shivdasani (2006), we also examine how the inclusion of firm fixed effects influences the empirical association between busy directors and firm performance. Furthermore, we explore how controlling for firm fixed effects impacts the overall explanatory power of our models. Finally, we explore whether the relation between busy directors and firm performance differs pre- and post-Sarbanes Oxley.

Our results suggest that the contradictory findings in the literature are attributable to differences in both the samples studied and empirical design. Notably the inclusion or exclusion of smaller firms and firm fixed effects materially impacts the inferences drawn regarding busy directors. Specifically, when smaller firms are included in the sample we observe evidence of a positive relation between busy directors and firm performance. Once we control for firm fixed effects, we find a consistent negative relation between busy directors and firm performance, regardless of sample composition. Moreover, the adjusted- $R^{2}$ of our models increases dramatically with the inclusion of firm fixed effects, suggesting that unobserved firm heterogeneity is also important in explaining the variation in firm performance. We also find evidence suggesting that busy boards lead to lower firm values, and that this association has weakened following the passage of the Sarbanes-Oxley Act.

Finally, we examine alternative measures of what constitutes a busy director and thus a busy board. We start with the definition that is increasingly used in the literature whereby an independent director serving on three or more boards is classified as busy. ${ }^{2}$ However we also explore different proxies for director busyness. Our alternative busyness measures are designed to account for the differential time and effort required to serve on the boards of different firms. For example, board service for a director on a small single-product line company may be less onerous than serving on the board of a fast growing and complex multinational corporation.

We find evidence that the relatively straightforward definition of busy directors (and thus busy boards) is as informative as the more complex, and data intensive, alternatives that we examine. Specifically, we find relatively high correlations between the traditional definitions of board busyness and the 
alternatives that we construct. Additionally, the empirical relations we observe with the alternative measures are qualitatively similar to those of the traditional measures, and they have similar explanatory power.

In Section 2 we review the relevant literature and highlight the disparate results. Section 3 outlines the data and variables used in the study while in Section 4 we report our primary findings. In Section 5 we explore alternative measures of director busyness. Section 6 concludes.

\section{Literature review}

The evidence on the association between busy directors and firm value is mixed. Fama and Jensen (1983) argue that directors who demonstrate their ability as monitors are rewarded with additional board appointments. Consistent with this view, Brickley et al. (1999) find that the likelihood that a retired CEO sits on his own board or other boards is positively associated with the performance of his firm while he was CEO. More recently, Ferris et al. (2003) find that the better the performance of firms at which the director serves, the more likely the director is to hold more board seats going forward. Conversely, Gilson (1990) finds that directors at financially distressed firms hold fewer board seats in the future. Similarly, Shivdasani, 1993, Harford, 2003 report that outside directors at firms that are the target of a hostile takeover attempt hold fewer board seats going forward. The findings that directors associated with better performing firms hold more directorships, while those associated with poor performing firms hold fewer, are consistent with multiple board seats certifying director quality. Therefore, these results suggest a positive relation between busy directors and firm performance.

Additional evidence consistent with the assertion that multiple directorships certify director quality can be found in Beasley, 1996, Cotter et al., 1997, Brown and Maloney, 1999, Ferris et al., 2003, amongst others. Beasley (1996) finds that firms whose outside directors hold more board seats are less likely to commit fraud. Cotter et al. (1997) report that when a merger target's board includes individuals with multiple board seats, the merger premium offered is higher. Similarly, Brown and Maloney (1999) find higher acquirer returns when directors with multiple board seats serve on the acquirer's board. Lastly, Ferris et al. (2003) report positive returns when firms announce the appointment of a director with multiple board seats.

In contrast to the certification view, some researchers argue that directors over-commit themselves as they take on multiple board seats and this reduces their efficacy as advisors and monitors. Related to this, Shivdasani and Yermack (1999) examine CEO involvement with the nomination of new directors and find that CEOs tend to select directors who (1) are predisposed to monitor management less and (2) have multiple board seats. Further, Core et al. (1999) report that CEO compensation is higher when outside directors hold multiple board seats, while Fich and Shivdasani (2006) find that firms where the majority of outside directors have multiple board seats have worse performance and are less likely to fire a CEO for poor performance. More recently, Ahn et al. (2010) find that acquiring firms where directors hold more seats experience more negative acquisition announcement returns while Jiraporn et al. (2008) report larger diversification discounts when directors hold multiple board seats (an effect that is exacerbated at firms with weaker shareholder rights). 
Fich and Shivdasani (2006) also find evidence of positive announcement returns when a busy director leaves a board, and they find that in response to news of a director accepting a third board seat, the incumbent firm experiences a negative announcement return. Additionally, Jiraporn et al. (2009) find that busier directors are more likely to miss board meetings, consistent with directors becoming over committed. Lastly, Jiraporn et al. (2009) find a U-shaped relationship between the number of board seats a director holds and the number of board committees he serves on. Specifically, when a director sits on a small number of boards, he serves on fewer committees suggesting, the director is busy. However, as a director sits on more boards, he serves on more committees, supporting the reputation hypothesis.

The discussion above outlines the debate and highlights the contradictory results in the literature. Both views are intuitively appealing, and both have empirical support in the literature. We attempt to reconcile the findings in the prior literature by using a representative analysis of how firm value is associated with board structure. Specifically, we focus on how differences in experimental design influence the link between board busyness and firm value. In doing so, we focus on sample differences, the specific methodologies used, and various proxies for director busyness.

\section{Data}

\subsection{Sample construction}

Using RiskMetrics, we obtain director and board-level data including name, age, ownership, board tenure, independence, committee appointments, and whether or not the director is a current CEO. Firm-level accounting and financial data are from COMPUSTAT, while stock market data are from Center for Research in Security Prices (hereafter CRSP). We exclude financial and utility firms and exclude observations where all the required data is not available. This results in a sample of 11,494 firm-years from 1999-2008. ${ }^{3}$ Table 1 presents descriptive statistics for the firms in the sample.

Table 1. Descriptive statistics.

Variable

Firm characteristics

Tobin's $Q$

Return on assets

Return on sales

Sales/assets

Operating margin

Total assets

Total sales

Board ownership

Board size
All firms

Mean Median
S\&P $\mathbf{5 0 0}$ firms

Mean Median
Non-S\&P 500 firms

Mean Median

$\begin{array}{llllll}2.03 & 1.60 & 2.25 & 1.79 & 1.93 & 1.53 \\ 0.13 & 0.13 & 0.16 & 0.15 & 0.13 & 0.12 \\ 0.14 & 0.13 & 0.19 & 0.17 & 0.12 & 0.12 \\ 1.12 & 0.96 & 1.05 & 0.90 & 1.15 & 1.00 \\ 0.13 & 0.13 & 0.15 & 0.15 & 0.12 & 0.12 \\ 6,059 & 1,344 & 17,231 & 7,039 & 1,372 & 792 \\ 4,851 & 1,305 & 12,978 & 6,307 & 1,441 & 804 \\ 1.22 & 1.00 & 1.16 & 1.00 & 1.25 & 1.00 \\ 8.94 & 9.00 & 10.50 & 10.00 & 8.29 & 8.00\end{array}$




\begin{tabular}{lllllll} 
Variable & \multicolumn{2}{l}{ All firms } & \multicolumn{2}{l}{ S\&P 500 firms } & \multicolumn{2}{l}{ Non-S\&P 500 firms } \\
& Mean & Median & Mean & Median & Mean & Median \\
Independent directors (\%) & 0.69 & 0.71 & 0.75 & 0.77 & 0.67 & 0.67 \\
Busy directors (\%) & 0.16 & 0.11 & 0.27 & 0.25 & 0.11 & 0.00 \\
Busy board & 0.09 & 0.00 & 0.19 & 0.00 & 0.05 & 0.00 \\
Average \# of directorships & 1.62 & 1.50 & 1.99 & 1.88 & 1.47 & 1.33 \\
Firm age & 22.76 & 16.00 & 34.71 & 32.00 & 17.75 & 13.00 \\
Number of segments & 2.36 & 2.00 & 2.72 & 3.00 & 2.21 & 2.00
\end{tabular}

Notes: This table presents descriptive statistics the firm and board characteristics. Tobin's $Q$ is calculated as the market value of the firm's equity at the end of the year plus the difference between the book value of the firm's assets and the book value of the firm's equity at the end of the year, divided by the book value of the firm's assets at the end of the year. Return on assets is calculated as operating income before depreciation plus the decrease in receivables, the decrease in inventory, the increase in current liabilities, and the decrease in other current assets scaled by the average of beginning- and ending-year book value of total assets. Return on sales is computed as operating income over net sales. Operating margin is estimated as annual operating income standardized by total assets. Total assets and total sales are those reported by Compustat at year-end. Board size is the firm's total number of directors. Board ownership is a quintile ranking of the percent of the firm's total outstanding equity held by the firm's directors. Independent directors (\%) is the number of independent directors divided by board size. Busy Directors (\%) is the percentage of independent directors who are busy, Busy Board is an indicator variable that takes a value of one if a majority of the independent directors are busy, and zero otherwise. Average \# of Directorships is the total number of directorships held by independent board members divided by the number of independent directors. Firm age is the number of years the firm has been in the CRSP database. Number of segments is the number of business segments reported by COMPUSTAT.

Similar to Ferris et al. (2003), we report the distribution of directors in our sample based on the number of board seats they hold in Table 2. Consistent with Ferris et al. (2003) we see that the percentage of directors holding multiple seats falls as the number of seats held increases. For example, we find that $28.3 \%$ of directors hold two board seats, while less than $0.02 \%$ hold ten seats. Ferris et al. (2003) report that more than $84 \%$ of their director sample holds just one board seat; the corresponding statistics for our sample is $47.4 \%$. That is, the majority of directors in our sample serve on multiple boards. We also note that directors who serve on the boards of S\&P 500 companies are more likely to serve on multiple boards relative to non-S\&P 500 directors. Specifically, we find that only $35.4 \%$ of S\&P directors hold a single board seat, while this percentage increases to $52.4 \%$ for non-S\&P 500 directors.

Table 2. Distribution of directorships held.

\section{Directorships held}

1

2

3

4

5
All firms: Directors

5449

3255

1701

701

245
$47.41 \%$

$28.32 \%$

$14.80 \%$

$6.10 \%$

$2.13 \%$
S\&P 500 directors

$1205 \quad 35.47 \%$

1034

677

296

116
$30.44 \%$

$19.93 \%$

$8.71 \%$

$3.41 \%$
Non-S\&P 500 directors

4244

2221

1024

405

129
$52.41 \%$

$27.43 \%$

$12.65 \%$

$5.00 \%$

$1.59 \%$ 


\begin{tabular}{llllllc} 
Directorships held & \multicolumn{2}{l}{ All firms: Directors } & \multicolumn{2}{c}{ S\&P $\mathbf{5 0 0}$ directors } & \multicolumn{2}{c}{ Non-S\&P $\mathbf{5 0 0}$ directors } \\
6 & 78 & $0.68 \%$ & 37 & $1.09 \%$ & 41 & $0.51 \%$ \\
7 & 46 & $0.40 \%$ & 20 & $0.59 \%$ & 26 & $0.32 \%$ \\
8 & 17 & $0.15 \%$ & 11 & $0.32 \%$ & 6 & $0.07 \%$ \\
10 & 2 & $0.02 \%$ & 1 & $0.03 \%$ & 1 & $0.01 \%$ \\
Total directors & 11,494 & & 3397 & & 8097 & \\
Number of firms & 2077 & & 532 & & 1545
\end{tabular}

Notes: We report the distribution of directors based on the number of directorships held. We report the number and percentage of individual directors holding the reported number of board seats for the full sample, the S\&P 500 , and the non-S\&P 500.

\subsection{Busy director proxies}

We use several different measures to capture the concept of director busyness. We classify these measures into two broad groups: (1) conventional measures used in the prior literature and (2) alternative measures that are designed to capture the nuances of busyness. We focus on independent directors as these directors are primarily responsible for monitoring management while inside directors are potentially on boards for other reasons. ${ }^{4}$

The conventional busy measures we use are the Fich and Shivdasani (2006)Percentage of busy directors which is the percentage of independent directors that are busy, where a director is considered to be busy if he or she serves on three or more boards, and the Busy board indicator, which takes the value of 1 if over $50 \%$ of the firm's independent directors are busy. Additionally, we calculate the Average number of directorships - the mean number of board seats held by independent directors - used by Ferris et al. (2003). These are relatively simple measures, treating all directorships the same. However, as noted earlier, one might expect that the demands on a director's time will vary with the characteristics of the firms where the director serves. That is, board service for a director on a small single-product line company may be less onerous than serving on the board of a fast growing complex multinational corporation. Thus, our alternative proxies for busy are designed to account for the differential time and effort required to serve at different firms.

We attempt to capture different firm and director characteristics that likely place greater demands on a director's time. At a general level we focus on two dimensions: (1) the complexity of the firms at which the director serves and (2) additional time commitments that the individual may face. To proxy for complexity we focus on firm size, the number of business segments, and R\&D intensity. Our priors are that these firm characteristics are associated with the time and effort required of the director to monitor and advise management. For time commitments we track whether or not the individual is a sitting executive at another S\&P 1500 firm, serves on numerous board committees (as defined below), and whether or not the director serves on the boards of firms operating in different industries. Our expectation is that sitting executives will have less time available for monitoring and advising because of the requirements of their careers. Similarly, directors serving on numerous committees have less time available and this in turn impinges on their ability to monitor and advise management. ${ }^{5}$ Lastly, serving on the boards of firms in diverse industries require more effort in order for the director to remain informed on industry-specific developments across multiple industries. 
Our complexity measures are: Busy directors serving at a large firm (\%) is the proportion of independent directors serving on three or more boards, where at least one of those firms has assets above the sample median; Busy directors serving firms with multiple business segments (\%) is the fraction of independent directors serving on three or more boards, where at least one firm has more business segments than the sample median; Busy directors serving firms with large R\&D expenditures $(\%)$ is the percentage of independent directors serving on three or more boards, where at least one firm has R\&D expenditures above the sample median. Our time constraint measures are: Busy directors serving as insiders at their firm (\%) is the percentage of independent directors serving on three or more boards, where they serve as an inside director on their employer's board; Busy directors with multiple committees (\%) is the percentage of independent directors serving on three or more boards who also serve on more than four committees (which is the median number of committee appointments for independent directors). Busy directors serving different industries (\%) is the percentage of independent directors serving on three or more boards, where at least two firms are in different Fama-French 48 industries.

\subsection{Dependent variables}

For purposes of comparison we generally follow the empirical approach of Fich and Shivdasani (2006). We focus primarily on the relation between busy directors and Tobin's $Q$, but we also examine Return on Assets (ROA), Sales as a Percent of Assets, and Return on Sales (ROS). We calculate Tobin's $Q$ as the market value of the firm's equity plus the difference between the book value of the firm's assets and equity, divided by the book value of the firm's assets all measured at the end of the year. ${ }^{6}$ We calculate ROA as the sum of operating income before depreciation plus the decrease in receivables, the decrease in inventory, the increase in current liabilities, and the decrease in other current assets, divided by the average of the beginning and year end book value of total assets. Sales as a Percent of Assets is calculated as sales divided by the average of beginning and year end book value of total assets. Return on Sales is calculated as the sum of operating income before depreciation plus the decrease in receivables, the decrease in inventory, the increase in current liabilities, and the decrease in other current assets, divided by sales.

\subsection{Control variables}

We control for: the natural log of the number of directorships held by the firm's CEO; the presence of a director with industry expertise (specifically, a director who serves on at least three boards where the majority of the firms are in the same industry as the firm); director ownership; board interlocks (where the firm's CEO sits on an outside director's board); CEO ownership; the log of board size; the number of standing board committees; the percentage of independent directors; ROA; log sales; firm age; growth opportunities (measured as depreciation expense scaled by total sales) and the number of business segments. A detailed explanation of each of the variables we examine is presented in Appendix B. While we do not control for board meeting frequency, as meeting frequency is missing for approximately $16 \%$ of our sample, in unreported tests controlling for meeting frequency we obtain qualitatively similar results. 


\section{Empirical results}

\subsection{Tobin's $Q$}

Table 3 reports the results of our multivariate analysis of the relation between busy directors and firm performance. Panel A presents evidence consistent with Ferris et al. (2003) that busy directors are associated with improved firm performance. Whether we examine the proportion of busy directors, the busy board indicator (Fich and Shivdasani (2006), Models 1 and 2), or average directorships (Ferris et al. (2003), Model 3), we find a positive association between busy directors and Tobin's $Q$. This suggests that the cross-sectional results of Ferris et al. (2003) are robust to different proxies for director busyness and the use of samples from different time periods.

Table 3. Busy directors and Tobin's $Q$.

\section{Variables}

Panel A: All firms

Board characteristics

Busy directors (\%)

Busy board (1/0)

Average \# directorships

Control variables

Board and firm controls (Fich and Shivdasani, 2006)

Year effects

Industry effects

Firm fixed effects

Adjusted $R^{2}$

Panel B: S\&P 500 firms

Board characteristics

Busy independent directors (\%)

Busy board (1/0)

Average \# directorships

Control variables

Board and firm controls (Fich and Shivdasani, 2006)

Year effects

Industry effects

Firm fixed effects

Adjusted $R^{2}$
(1)

$0.456^{* * *}$
(3)

(2)

$\begin{array}{lll}\text { Yes } & \text { Yes } & \text { Yes } \\ \text { Yes } & \text { Yes } & \text { Yes } \\ \text { Yes } & \text { Yes } & \text { Yes } \\ \text { No } & \text { No } & \text { No }\end{array}$

$17.08 \% \quad 16.76 \%$

$16.98 \%$

Panel C: Non-S\&P 500 firms

Board characteristics

$-0.130^{* *}$

$-0.091^{* *}$

$\begin{array}{lll}\text { Yes } & \text { Yes } & \text { Yes } \\ \text { Yes } & \text { Yes } & \text { Yes } \\ \text { Yes } & \text { Yes } & \text { Yes } \\ \text { No } & \text { No } & \text { No } \\ \text { 36.83\% } & 36.82 \% & 36.86 \%\end{array}$


Variables

Busy independent directors (\%)

Busy board (1/0)

Average \# directorships

Control variables

Board and firm controls (Fich and Shivdasani, 2006)

Year effects

Industry effects

Firm fixed effects

Adjusted $R^{2}$ (\%)
(1)

$0.357^{* * *}$

(2)

$0.174^{* *}$

$0.152^{* * *}$

$\begin{array}{lll}\text { Yes } & \text { Yes } & \text { Yes } \\ \text { Yes } & \text { Yes } & \text { Yes } \\ \text { Yes } & \text { Yes } & \text { Yes } \\ \text { No } & \text { No } & \text { No } \\ 18.89 & 18.70 & 18.79\end{array}$

Notes: This table presents the results of our multivariate analysis of the association between busy directors and Tobin's $Q$. Tobin's $Q$ is calculated as the market value of the firm's equity at the end of the year plus the difference between the book value of the firm's assets and the book value of the firm's equity at the end of the year, divided by the book value of the firm's assets at the end of the year. Busy directors (\%) is the percentage of independent directors that hold three or more directorships. Busy board $(1 / 0)$ is an indicator variable equal to one if $50 \%$ or more of the board's independent directors hold three or more directorships. Average \# directorships is the total number of directorships held by the firm's independent directors, divided by the number of independent directors. We control for year and industry fixed effects. A list of the other control variables used and details regarding their calculation is provided in Appendix B. Panel A presents the results for the full sample, while Panels B and C report the results for the S\&P 500 and non-S\&P-500 sub-samples respectively.

"Statistical significance at the $10 \%$ level, respectively.

$* * *$ Statistical significance at the $1 \%$ level, respectively.

**Statistical significance at the $5 \%$ level, respectively.

Of note, however, Fich and Shivdasani (2006) examine a panel of Fortune 500 firms between 1989 and 1995, while Ferris et al. (2003) analysis is of a cross-section of more than 3000 COMPUSTAT firms in 1995. Thus, it is possible that the different sample selection procedure accounts for the disparate empirical findings. We explore this possibility in Panels $B$ and $C$ of Table 3 where we split the sample into S\&P 500 firms (Panel B) and non-S\&P 500 firms (Panel C). In Panel B we see that Tobin's $Q$ is inversely related to the presence of busy directors for S\&P 500 firms, consistent with Fich and Shivdasani (2006). However, in Panel C for the non-S\&P 500 firms, the opposite is true - that is, consistent with the Ferris et al. (2003) findings, there is a positive association between busy directors and Tobin's $Q$.

Our ability to replicate the results of these two papers by splitting the sample based on S\&P 500 membership (to approximate the different sample selection methodologies of the two papers) suggests a possible explanation for the different conclusions. Namely, that the relation between busy directors and firm performances is contingent on the type of firm examined. Additionally, our results suggest a possible explanation as to why Fich and Shivdasani (2006) were unable to reproduce the Ferris et al. (2003) findings. Ferris et al. (2003) examines a sample that is dominated by smaller nonFortune 500 (and non-S\&P 500) firms, for which our results suggest a positive relation between busy directors and performance. Fich and Shivdasani (2006) examine only Fortune 500 companies, where 
our results suggest a negative relation between busy directors and performance for similar firms. The focus on larger companies by Fich and Shivdasani (2006) likely precluded them from finding evidence of a negative relation between busy directors and performance. While our results suggest the importance of sample selection for the previously documented findings, we note that the results of both papers are robust in the sense that we can replicate them for a more recent time period.

Of course, the use of different empirical approaches may also be important in explaining the different results from these papers. Fich and Shivdasani (2006) argue that fixed effects analysis offers more reliable estimates. Consistent with this, Brookman and Thistle, 2011, Coles and Li, 2011, and Graham et al. (2012), suggest the need to control for unobservable firm characteristics when analyzing corporate finance issues. Specifically, these papers find that including firm fixed effects alters previously documented results when examining CEO pay.

Table 4 presents the results of our analysis when we include firm fixed effects. Panel A reports results for the full sample and Panels B and C report the results for the S\&P 500 and non-S\&P 500 samples, respectively. Once we control for firm fixed effects, we find a consistent negative relation between busy directors and firm performance, regardless of the sample examined or the busy director proxy used. These results demonstrate the importance of controlling for firm fixed effects. Absent a control for fixed effects, the relation between busy directors and firm performance appears to be sample specific. However, once we control for firm fixed effects, we find a consistent negative relation between busy directors and performance. Additionally, we note the significant increase in our adjusted $R^{2}$. The inclusion of fixed effects increases our explanatory power by $100-300 \%$.

Table 4. Busy directors and Tobin's $Q$ controlling for firm-fixed effects.

Variables

Panel A: All firms

Board characteristics

Busy directors (\%)

Busy board (1/0)

Average \# directorships

Control variables

Board and firm controls (Fich and Shivdasani, 2006)

Year effects

Industry effects

Firm fixed effects

Adjusted $R^{2}$

Panel B: S\&P 500 firms

Board characteristics

Busy independent directors (\%)

$-0.324^{* * *}$

Busy board (1/0)
$-0.145^{* *}$

(2)

(3)

$-0.019$

$-0.054^{* *}$

$\begin{array}{lll}\text { Yes } & \text { Yes } & \text { Yes } \\ \text { Yes } & \text { Yes } & \text { Yes } \\ \text { Yes } & \text { Yes } & \text { Yes } \\ \text { Yes } & \text { Yes } & \text { Yes } \\ 68.54 \% & 68.53 \% & 68.54 \%\end{array}$


Variables

Average \# directorships

Control variables

Board and firm controls (Fich and Shivdasani, 2006)

Year effects

Industry effects

Firm fixed effects

Adjusted $R^{2}$

Panel C: Non-S\&P 500 firms

Board characteristics

Busy independent directors (\%)

Busy board (1/0)

Average \# directorships

Control variables

Board and firm controls (Fich and Shivdasani, 2006)

Year effects

Industry effects

Firm fixed effects

Adjusted $R^{2}(\%)$
(1)

(2)

(3)

$-0.083^{*}$

$\begin{array}{lll}\text { Yes } & \text { Yes } & \text { Yes } \\ \text { Yes } & \text { Yes } & \text { Yes } \\ \text { Yes } & \text { Yes } & \text { Yes } \\ \text { Yes } & \text { Yes } & \text { Yes } \\ 72.69 \% & 72.69 \% & 72.74 \%\end{array}$

$-0.206^{* *}$

$-0.102^{*}$

$-0.109^{* * *}$

$\begin{array}{lll}\text { Yes } & \text { Yes } & \text { Yes } \\ \text { Yes } & \text { Yes } & \text { Yes } \\ \text { Yes } & \text { Yes } & \text { Yes } \\ \text { Yes } & \text { Yes } & \text { Yes } \\ 70.66 & 70.63 & 70.63\end{array}$

Notes: This table presents the results of our multivariate analysis of the association between busy directors and Tobin's $Q$ controlling for firm-fixed effects. Tobin's $Q$ is calculated as the market value of the firm's equity at the end of the year plus the difference between the book value of the firm's assets and the book value of the firm's equity at the end of the year, divided by the book value of the firm's assets at the end of the year. Busy directors $(\%)$ is the percentage of independent directors that hold three or more directorships. Busy board (1/0) is an indicator variable equal to one if $50 \%$ or more of the board's independent directors hold three or more directorships. Average \# directorships is the total number of directorships held by the firm's independent directors, divided by the number of independent directors. We control for year and industry fixed effects. A list of the other control variables used and details regarding their calculation is provided in Appendix B. Panel A presents the results for the full sample, while Panels $B$ and $C$ report the results for the S\&P 500 and non-S\&P500 sub-samples respectively.

$* * *$ Statistical significance at the $1 \%$ level respectively.

**Statistical significance at the $5 \%$ level respectively.

*Statistical significance at the $10 \%$ level respectively.

While the coefficients on our busy director measures are all negative, the busy board indicator is not statistically significant in the full sample analysis but is significant in both sub-samples. This is somewhat surprising but is potentially explained by a structural break between the two sub-samples. ${ }^{7}$ That is, while busy boards are negatively associated with firm performance in both sub-samples, the full sample analysis fails to control for the structural differences between S\&P 500 and non-S\&P 500 firms. 
We examine the economic significance of this relation by focusing on the subsample analyses presented in Table 4 Panels B and C; we estimate the change to average Tobin's $Q$ for each specification. We find that, from Model 1, if one non-busy independent director was to become busy, then Tobin's $Q$ would decline by approximately $1.98 \%$ for the S\&P 500 and $1.93 \%$ for the non-S\&P 500 firms. In Model 2, if the board were to become busy, it would result in a decline of 3.78\% and 5.28\% for the S\&P 500 and non-S\&P 500 firms, respectively. Finally, based on Model 3, if the average number of directorships were to increase by one then, the decline in Tobin's $Q$ would be $3.69 \%$ and $5.65 \%$ for the S\&P 500 and non-S\&P 500 firms, respectively.

\subsection{Sarbanes-Oxley}

Jiraporn et al. (2009) report that busy directors' behavior has changed since the passage of SarbanesOxley (SOX) in 2002 in that they are less likely to miss board meetings post-SOX. Therefore, it is reasonable to expect that the relation between busy directors and firm performance might also have changed post-SOX. We address this issue in Table 5. Following Jiraporn et al. (2009) we create a postSOX indicator variable, which we interact with our busyness proxies. ${ }^{8}$ While we find that busy directors and Tobin's $Q$ are negatively related, we find some evidence suggesting that the relation has weakened post-SOX. Specifically, the interaction between the average number of directorships and the post-SOX indicator is significantly positive, while the busy independent director (\%) and busy board interactions are both positive and insignificant. This is consistent with the Jiraporn et al. (2009) assertion that SOX has motivated directors to act more responsibly.

Table 5. Busy directors and Tobin's Q: pre and post-SOX.

\section{Variables}

Board characteristics

Busy independent directors (\%)

Busy independent directors $(\%)^{\natural}$ post-SOX

Busy board (1/0)

Busy board $(1 / 0)^{\square}$ post-SOX

Average \# directorships rectors

Average \# directorships ${ }^{\text {a }}$ post-SOX

\section{Control variables}

Board and firm characteristics (Fich and Shivdasani, 2006)

Industry effects

Firm fixed effects

Adjusted $R^{2}$ (\%)
(1)

(2)

(3)

$-0.236^{* * *}$

0.103

Notes: This table presents the results of our multivariate analysis of the association between busy directors and Tobin's $Q$ controlling for firm-fixed effects. Tobin's $Q$ is calculated as the market value of the firm's equity at the end of the year plus the difference between the book value of the firm's assets and the book value of the firm's equity at the end of the year, divided by the book value of the firm's assets at the end of the year. Busy directors $(\%)$ is the percentage of independent directors that hold three or more directorships. Busy board (1/0) is the indicator variable equal to one if $50 \%$ or more of the board's independent directors hold three or more 
directorships. Average \# directorships is the total number of directorships held by the firm's independent directors, divided by the number of independent directors. We control for year and industry fixed effects. A list of the other control variables used and details regarding their calculation is provided in Appendix B. Panel A presents the results for the full sample, while Panels $B$ and $C$ report the results for the S\&P 500 and non-S\&P500 sub-samples respectively.

${ }^{* *}$ Statistical significance at the $5 \%$ level, respectively.

$* * *$ Statistical significance at the $1 \%$ level, respectively.

*Statistical significance at the $10 \%$ level, respectively.

\subsection{Causality}

The results presented in Table 4, Table 5 suggest that busy directors are over committed, limiting their ability to monitor and advise management, which diminishes firm performance. However, the results do not allow us to identify causality. Busy directors may lead to lower Tobin's $Q$, as argued by the literature, or firms with lower Tobin's $Q$ may appoint more busy directors to their boards in order to implement change. To explore the direction of causality we use an approach analogous to that of Jiraporn et al. (2009). Specifically, we replace our busyness proxies with their respected lagged values and re-estimate the analysis in Panel A of Table 4 using 1, 2, and 3 year lags. The rationale is that director busyness in prior years could not have been caused by the firm's Tobin's $Q$ in subsequent years. $^{9}$

The untabulated results are consistent with those reported in Panel A of Table 4 in that we find negative relations between busyness and Tobin's $Q$. Specifically, busy independent director (\%) and average directorships held by independent directors are significantly negative, while the coefficient for the busy board indicator is negative but insignificant. On balance, these results lend support to the contention that busy directors detract from firm performance.

\subsection{Alternative performance measures}

The analysis above suggests that busy directors are negatively associated with firm performance. However, the analysis relies on Tobin's $Q$, which potentially suffers from significant measurement error. To ensure that our results are not driven by issues with Tobin's $Q$, we supplement our analysis by examining several alternative measures of firm performance. Following Fich and Shivdasani (2006) we examine return on assets, sales as a percent of assets and return on sales. In Table 6 we limit our analysis to the full sample and control for firm fixed effects, although we obtain qualitatively similar results in both the S\&P 500 and non-S\&P 500 sub-samples (not tabled).

Table 6. Busy directors and operating performance.

Variables

ROA

(1)

(2)

(3)

$-0.009^{*}$

directors (\%)

Busy board (1/0)

Average \#

directorships

$-0.005^{* *}$
Sales/assets

(1)

(2)

(3)

$-0.053^{* * *}$

$-0.007$

$-0.01^{* *}$

(1) (2)

$-0.023^{* *}$
(3)

$-0.004^{*}$ 
Variables

ROA

Sales/assets

ROS

(1)

(2)

(3)

(1)

(2)

(3)

(1)

(2)

(3)

Control variables

Board and firm

\begin{tabular}{|c|c|c|c|c|c|c|c|c|c|}
\hline $\begin{array}{l}\text { characteristics (Fich } \\
\text { and Shivdasani, } 2006\end{array}$ & Yes & Yes & Yes & Yes & Yes & Yes & Yes & Yes & Yes \\
\hline Year effects & Yes & Yes & Yes & Yes & Yes & Yes & Yes & Yes & Yes \\
\hline dustry effects & Yes & Yes & Yes & Yes & Yes & Yes & Yes & Yes & Yes \\
\hline rm fixed effects & Yes & Yes & Yes & Yes & Yes & Yes & Yes & Yes & Yes \\
\hline djusted $R^{2}(\%)$ & 77.71 & 77.71 & 77.70 & 92.93 & 92.93 & 92.93 & 77.99 & 77.99 & 77.99 \\
\hline
\end{tabular}

Notes: This table presents the results of our multivariate analysis of the association between busy directors and firm performance using alternative firm performance proxies. Return on assets is calculated as operating income before depreciation plus the decrease in receivables, the decrease in inventory, the increase in current liabilities, and the decrease in other current assets scaled by the average of beginning- and ending-year book value of total assets. Sales/assets is total sales divided by total assets. Return on sales is computed as operating income over net sales. Busy directors (\%) is the percentage of independent directors that hold three or more directorships. Busy board (1/0) is an indicator variable equal to one if $50 \%$ or more of the board's independent directors hold three or more directorships. Average \# directorships is the total number of directorships held by the firm's independent directors divided by the number of independent directors. We control for year-, industry-, and firm fixed-effects. A list of the other control variables used and details regarding their calculation is provided in Appendix B.

$* * *$ Statistical significance at the $1 \%$ level, respectively.

**Statistical significance at the $5 \%$ level, respectively.

*Statistical significance at the $10 \%$ level, respectively.

We see that all of the busy director proxies are negatively and significantly related to both ROA and ROS. While all three busy director proxies are negatively related to sales as a percent of assets, the busy board indicator is not statistically significant. The results presented in Table 6 suggest that busy directors are negatively related to firm performance, and that our previously observed relation is not driven by issues with Tobin's $Q$.

\section{Alternative measures of director busyness}

\subsection{Alternative board seat thresholds}

The analysis thus far follows the prior literature and assumes that directors become busy when they sit on three or more boards. We now examine how changing this definition of director busyness impacts the relation between busy directors and firm performances. Specifically, we reclassify directors as busy if they (1) serve on two or more boards or (2) four or more boards. Using these various classifications of busy directors, we re-estimate the relation between busy directors and firm performance. Moreover, we focus our analysis on the percentage of busy directors as it provides more consistent results than the busy board indicator or the average number of directorships. ${ }^{10}$ 
These results, presented in Table 7, suggest that the negative association between busy directors and firm performance is strongest when the definition of busy is a director serving on three or more boards. When we use the two board seat cutoff, the percentage of busy independent directors is only significantly related to sales as a percent of assets. Using the four board seat cutoff, the percentage of busy directors is only significantly related to Tobin's $Q$ and ROS. While using the three boards cut off, the percentage of busy directors is significantly negatively related to all of our firm performance measures. This suggests that classifying directors on three or more boards as busy is robust from an empirical perspective.

Table 7. Firm Performance Regressions with alternative thresholds for busyness.

Model Measures of busy independent directors

Busy directors $(\geqslant 2)(\%)$

Control variables

(1)

Board and firm characteristics (Fich and

Shivdasani, 2006)

Yes

Year and Industry effects

Firm fixed effects

Adjusted $R^{2}(\%)$

Busy directors $(\geqslant 3)(\%)$

Control variables

(2)

Board and firm characteristics (Fich and

Shivdasani, 2006)

Yes

Year and industry effects

Firm fixed effects

Adjusted $R^{2}$ (\%)

Busy directors $(\geqslant 4)(\%)$

\section{Control variables}

(3)

Board and firm characteristics (Fich and

Shivdasani, 2006)

Yes

Year and Industry effects

Firm fixed effects

Adjusted $R^{2}$ (\%)
Dependent variables

Tobin's $Q$

$-0.049$

ROA Sales/assets ROS

$-0.006-0.035^{* *}-0.004$

Yes

Yes

Yes

68.53

$-0.145^{* *}$

Yes Yes

Yes Yes

Yes Yes

77.7192 .93

Yes

Yes

77.97

$-0.009^{*}-0.053^{* * *}-0.023^{* *}$

Yes Yes Yes

Yes Yes Yes

Yes Yes Yes

68.54

$77.71 \quad 92.93$

$-0.207^{* *}$

$-0.007-0.018$

Yes

Yes

77.99

$-0.025^{*}$ 
Notes: This table presents the results of our multivariate analysis of the association between busy directors and firm performance using alternative definitions of what constitutes a busy director. Tobin's $Q$ is calculated as the market value of the firm's equity at the end of the year plus the difference between the book value of the firm's assets and the book value of the firm's equity at the end of the year, divided by the book value of the firm's assets at the end of the year. Return on assets is calculated as operating income before depreciation plus the decrease in receivables, the decrease in inventory, the increase in current liabilities, and the decrease in other current assets scaled by the average of beginning- and ending-year book value of total assets. Sales/assets is total sales divided by total assets. Return on sales is computed as operating income over net sales. Busy directors (\%) is the percentage of independent directors that hold: (1) Two or more directorships in Model 1, (2) three or more directorships in Model 2, and (3) four or more directorships in Model 3. We control for year-, industry-, and firm-fixed effects. A list of the other control variables used and details regarding their calculation is provided in Appendix $B$.

$* * *$ Statistical significance at the $1 \%$ level, respectively.

**Statistical significance at the $5 \%$ level, respectively.

*Statistical significance at the $10 \%$ level, respectively.

\subsection{Complexity and commitment measures}

To identify busy directors, the prior literature focuses exclusively on the number of directorships an individual holds: Core et al., 1999, Ferris et al., 2003, Fich and Shivdasani, 2006, Jiraporn et al., 2008, Jiraporn et al., 2009, Jiraporn et al., 2009, Ahn et al., 2010. While this is an intuitive approach, it fails to address the possibility that the demands placed on a director are different across firms. For example, all else equal, complex firms (i.e. those with many business segments) are more likely to require more time and effort from their directors than a firm with only a single business segment. Therefore, if two directors both serve on three boards, but one director serves on the board of more complex firms and all else is equal, then this director is busier.

Surprisingly, these various dimensions of busyness have not been addressed in-depth in prior work. Thus, in this section we explore how alternative busyness measures designed to capture variation in the time and effort needed to monitor and advise management are associated with each other and with firm performance. The alternative measures we examine focus on (1) variation in the complexity of the firms and (2) additional time constraints placed on the directors. To account for complexity, we focus on whether directors serve at large firms, firms with multiple business segments, or firms with large R\&D expenditures. To account for time constraints, we see if directors serve as inside directors at their own firm, have multiple committee obligations, or serve on the boards of firms in different industries.

Table 8 presents the correlation matrix between all of our busyness measures, while Table 9 presents the analysis of how our alternative busyness proxies are associated with firm performance. The results in Table 8 demonstrate that the alternative busyness measures are highly correlated with each other and with those used in the prior literature. This suggests that they may add little in explaining firm performance. The results presented in Table 9 are consistent with this notion. Specifically, we find that all of the busyness measures have a negative association with Tobin's $Q$. The adjusted $R^{2}$ suggests that the model specifications using the simple measures from the prior literature have just as much explanatory power as the more complex alternatives that we examine here, which are more complex, data intensive, and time consuming to construct. 
Table 8. Correlation matrix.

\section{Variables}

(1) Busy directors (\%)

(2) Busy board (1/0)

(3) Average \# directorships

(4) Busy directors serving large firms (\%)

(5) Busy directors serving firms with multiple business segments (\%)

(6) Busy directors serving firms with large R\&D expenditures (\%)

(7) Busy directors serving different industry (\%)

(8) Busy directors with multiple committees (\%)

(9) Busy directors serving as insiders at their firm (\%)

\section{Pearson correlation coefficients}
(1) (2)
(3)
(4) (5)
(6) (7)
(8) (9)

1.00

0.711 .00

0.900 .651 .00

0.950 .690 .881 .00

0.920 .660 .860 .901 .00

0.890 .640 .820 .850 .841 .00

0.940 .690 .870 .920 .890 .831 .00

0.810 .610 .790 .790 .770 .740 .791 .00

0.530 .390 .470 .510 .490 .490 .490 .291 .00

Notes: This table presents the correlations between the various measures of busy directors. Busy directors (\%) is the percentage of independent directors that hold three or more directorships. Busy board $(1 / 0)$ is the indicator that sets equal to one if $50 \%$ or more of the board's independent directors hold three or more directorships. Average \# directorships is the total number of directorships held by all of a firm's independent directors, divided by the number of independent directors. Busy directors serving large firms (\%) is the fraction of independent directors that serves on at least one firm whose total assets is above the sample median in the year. Busy directors serving firms with multiple business segments (\%) is the fraction of independent directors that serve on at least one firm with more business segments than the median in the sample for the year. Busy directors serving firms with large R\&D expenditures (\%) is the fraction of independent directors that serve on at least one firm's whose R\&D expenditures are above the median in a year. Busy directors with multiple committees (\%) is the fraction of busy directors that serve on four or more committees. Busy directors serving different industry (\%) is the fraction of independent directors that serve on firms in at least two Fama-French 48 industries. Busy directors serving as insiders at their firm (\%) is the fraction of independent directors that are an insider on their own firm's board.

Table 9. Firm performance regressions with alternative measures of busy directors.

\section{Model Measures of busy independent directors}

(1) Busy directors (\%)

Adjusted $R^{2}(\%)$

(2) Busy board (1/0)

Adjusted $R^{2}$ (\%)

(3) Average \# directorships

Adjusted $R^{2}(\%)$

(4) Busy directors serving large firms (\%)
Dependent Variables

Tobin's

Q

ROA Sales/Assets ROS

$-0.145^{* *}-0.009^{*}-0.053^{* * *} \quad-0.023^{* *}$

$\begin{array}{llll}68.54 & 77.71 & 92.93 & 77.99\end{array}$

$-0.019-0.005^{* *}-0.007 \quad-0.01^{* *}$

$\begin{array}{llll}68.53 & 77.71 & 92.93 & 77.99\end{array}$

$-0.054^{* *}-0.004^{*}-0.018^{* * *}-0.008^{* *}$

$\begin{array}{llll}68.54 & 77.71 & 92.93 & 77.99\end{array}$

$\begin{array}{lll}-0.177^{* *}-0.009^{*}-0.03 & -0.025^{* *}\end{array}$ 
Model Measures of busy independent directors

Adjusted $R^{2}(\%)$

(5)

Busy directors serving firms with multiple business segments (\%)

Adjusted $R^{2}(\%)$

(6)

Busy directors serving firms with large R\&D expenditures (\%)

Adjusted $R^{2}$ (\%)

(7) Busy directors with multiple committees (\%)

Adjusted $R^{2}$ (\%)

(8) Busy directors serving different industry (\%)

Adjusted $R^{2}$

Busy directors serving as insiders at their firm (\%)

Adjusted $R^{2}(\%)$

Dependent Variables

Tobin's

$Q$

ROA Sales/Assets ROS

$68.55 \quad 77.71 \quad 92.93 \quad 77.99$

$\begin{array}{cccc}-0.232^{* * *}-0.008 & -0.043^{* *} & -0.012 \\ 68.56 & 77.70 & 92.93 & 77.98\end{array}$

$-0.084-0.009^{*}-0.056^{* * *}-0.02^{*}$

$\begin{array}{llll}68.53 & 77.71 & 92.93 & 77.98\end{array}$

$-0.174^{* *}-0.006-0.031-0.023^{* *}$

$\begin{array}{llll}68.54 & 77.70 & 92.93 & 77.98\end{array}$

$-0.207^{* * *}-0.007-0.037^{*} \quad-0.028^{* * *}$

$\begin{array}{llll}68.56 & 77.70 \quad 92.93 & 77.99\end{array}$

$\begin{array}{llll}-0.252^{*} & -0.015 & -0.014 \quad-0.011\end{array}$

$68.54 \quad 77.71 \quad 92.92 \quad 77.98$

Notes: This table presents the results of our multivariate analysis of the effect of busy directors on firm performance, using various proxies for busy directors and controlling for firm-fixed effects. Tobin's $Q$ is calculated as the market value of the firm's equity at the end of the year plus the difference between the book value of the firm's assets and the book value of the firm's equity at the end of the year, divided by the book value of the firm's assets at the end of the year. Return on assets is calculated as operating income before depreciation plus the decrease in receivables, the decrease in inventory, the increase in current liabilities, and the decrease in other current assets scaled by the average of beginning- and ending-year book value of total assets. Sales/assets is total sales divided by total assets. Return on sales is computed as operating income over net sales. Busy directors (\%) is the percentage of independent directors that hold three or more directorships. Busy board (1/0) is an indicator equal to one if $50 \%$ or more of the board's independent directors hold three or more directorships. Average \# directorships is the total number of directorships held by all of a firm's independent directors, divided by the number of independent directors. Busy directors serving large firms (\%) is the fraction of independent directors that serve on at least one firm whose total assets is above the sample median in the year. Busy directors serving firms with multiple business segments (\%) is the fraction of independent directors that serve on at least one firm with more business segments than the median in the sample for the year. Busy directors serving firms with large R\&D expenditures (\%) is the fraction of independent directors that serve on at least one firm's whose R\&D expenditures are above the median in a year. Busy directors with multiple committees (\%) is the fraction of busy directors that serve on four or more committees. Busy directors serving different industry (\%) is the fraction of independent directors that serve on firms in at least two Fama-French 48 industries. Busy directors serving as insiders at their firm (\%) is the fraction of independent directors that are an insider on their own firm's board. We control for year and industry fixed effects $A$ list of the other control variables used as well as details regarding their calculations is provided in Appendix B.

$* * *$ Statistical significance at the $1 \%$ level, respectively.

**Statistical significance at the $5 \%$ level, respectively.

*Statistical significance at the $10 \%$ level, respectively. 


\section{Conclusions}

Prior work has documented both positive and negative relations between busy directors and firm value. We attempt to reconcile these disparate results in the literature and explore whether or not more comprehensive definitions of what constitutes a busy director affects inferences regarding this association. In doing so, we focus on a more recent sample and find evidence consistent with the prior literature. Specifically, when focusing on larger firms, namely S\&P 500 firms, we find evidence of a negative association between the presence of busy directors and firm performance. This is consistent with Fich and Shivdasani's (2006) analysis of the Forbes 500. However, when studying a larger sample including non-S\&P 500 firms, we find evidence that the presence of busy directors is positively related to firm performance, consistent with Ferris et al. (2003). Our ability to find results consistent with both Fich and Shivdasani, 2006, Ferris et al., 2003 suggests that the conflicting findings of these papers are potentially the result of differences in the samples studied.

However, the specific empirical approach used may also account for differences. Indeed, following the arguments of Fich and Shivdasani, 2006, Brookman and Thistle, 2011, Coles and Li, 2011, and Graham et al. (2012), once we control for firm fixed effects, we find a consistent negative relation between busy directors and firm performance, regardless of the sample examined. Our finding of a consistent negative association between busy directors and firm performance across samples in this analysis reinforces the need for researchers to control for firm fixed effects in such analyses. Failing to control for unobservable firm characteristics can result in a mis-specified model and potentially incorrect inferences. Our results are also suggestive of causality running from busy board to (lower) firm value. Furthermore, we find evidence that the link has weakened post-Sarbanes-Oxley.

Lastly, we examine whether or not the definition of what constitutes a busy director affects the empirical association between busy directors and performance. Specifically, we examine alternatives to the three board seat as a cutoff for busyness, proxies that account for the complexity of the firms where the director serves, and time commitments. Our findings suggest that the relatively straightforward definition used in the prior literature of a busy director as serving on three or more boards, is appropriate and as informative as the more complex and data-intensive proxies that we examine. This implies that future researchers can avoid the data collection and cleaning associated with the busyness measures we examine and focus on the relatively straightforward proxy used in the prior literature.

\section{Appendix A. Sample construction}

\section{A.1. RiskMetrics}

Our primary data source is RiskMetrics, which we obtain through ISS Governance Services. While the data was initially provided by the Investor Responsibility Research Center (IRRC), ISS acquired RiskMetrics in 2005. Following the acquisition, in 2007 the methodology used for data collection was changed. Thus, RiskMetrics provides two datasets: (1) the legacy version, covering 1996-2006, which was collected using the old IRRC methodology and (2) the current version starting in 2007, that follows the new ISS methodology. This change in the methodology reduced the number of variables collected. The legacy version contained 79 variables while the current version contains only 64 variables. 
Additionally, some data item names where changed, as was how some data was recorded. ${ }^{11}$ Combining the two versions of the RiskMetrics dataset provides us with a sample of 193,467 director-year level observations for which we have 61 variables in common across the two datasets.

We remove 20 observations from this sample as they appear to be duplicate observations.

Additionally, we remove all observations for P-COM 1999, as a board and director information across years is constant. Due to the use of lagged variable, the sample period is between 1999 and 2008 and there are 145,778 director-year observations and 15,501 firm-year observations.

\section{A.2. Company IDs}

RiskMetrics provides three company identifiers that can potentially be used to match with other databases: six-digit CUSIP number, ticker, and company name. Of these three, the CUSIP is generally regard as the more reliable for matching across databases. However, the CUSIP contains missing observations, as well as coding errors. Specifically, the six digit CUSIP used in RiskMetrics is supposed be the first six numbers in the standard eight digit CUSIP, but we find coding errors in this field. In addition to the three general company identifiers, RiskMetrics provides several internal company identifiers. The legacy version contains legacy_pps_id, and $r t$ id (for the period following RiskMetrics's acquisition by ISS), while the current version provides company_id, and $r t_{-} i d$. Unfortunately, none of these identifiers uniquely identifies companies in the combined version of RiskMetrics. The specific problem is that no single identifier covers all of a firm's observations within the dataset. Therefore, we create our own unique company identifier within RiskMetrics, coid. Assuming that each internal identifier correctly identifies specific firm observations, we combine the three identifiers into a unique company id. We start by setting coid to $r t$ id, we then fill in missing values for coid by expanding $r t i d$ to any observation that shares a legacy_pps_id. We then repeat this process using company_id. This process successfully identifies all observations in our sample. We next merge our RiskMetrics data to CRSP and Compustat.

This is not a simple matching procedure as the RiskMetrics identifier appears to change. Therefore, we follow the methodology listed below.

1. Match observations based on six-digit CUSIP, ticker, and year.

2. Match remaining observations based on six-digit CUSIP and year.

3. Match remaining observations based on ticker and year.

However, this may result in multiple permnos for an individual company. To identify a unique permno for each company:

1. If all permnos cover the entire sample period, we select the permno with the highest trading volume.

2. If the permnos are mutually exclusive, we assume each is correct

3. If the permnos are not mutually exclusive, we assign the permno with the longest time covered as the firm's permno.

4. We manually identify the 79 firm-years that this methodology fails to identify. 


\section{A.3. Director-level information}

In addition to creating a unique firm identifier, we also correct coding errors in the director-level information. Director information, such as gender, should remain constant. Similarly, the year a director's tenure at a firm started should remain constant. To correct for these types of inconsistencies, we perform the following steps: (1) extract all observations with missing and inconsistent values, (2) if an observation has missing values but the rest of the observations provide consistent values, then replace the missing observation with the consistent value, (3) if the values are inconsistent through a director (or director-firm), replace the inconsistent values with the value that appears the most frequently. Any inconsistencies remaining after these steps are manually corrected. ${ }^{12}$

\section{A.4. CEO information}

Riskmetrics does not explicitly identify a firm's CEO. For the majority of firms we are able to identify a firm's CEO by combining the inside director indicator and the insider position variables. When this criterion fails to identify the firm's CEO, we use the following criteria: If a firm has only one insider on the board, we classify that director as the CEO. Alternatively, we classify inside directors that are the chairman of the board as the CEO. If we are still unable to identify the CEO, we use EXECUCOMP, and proxy statements to identify the CEO. After checking proxy statements, we are unable to identify the CEO for 55 firm-year observations. We drop these observations from the sample.

\section{Appendix B. Variable definitions}

\section{Dependent variables}

Tobin's $Q$

The market value of the firm's equity plus the difference between the book value of the firm's assets and the book value of the firm's equity, divided by the book value of the firm's assets. All data is from year end

The sum of operating income before depreciation plus the decrease in

ROA receivables, the decrease in inventory, the increase in current liabilities, and the decrease in other current assets, divided by the average of the beginning and year end book value of total assets

Sales as a percent of assets

Sales divided by total assets

The sum of operating income before depreciation plus the decrease in

ROS receivables, the decrease in inventory, the increase in current liabilities, and the decrease in other current assets, divided sales

Busyness variables

Conventional

Busy director (\%)

The percentage of independent directors who hold three or more directorships

Busy boards

An indicator set to 1 if over $50 \%$ of the board's independent directors are busy 
Average \# directorships

\section{Alternative}

Busy director serving a large firm

Busy director serving a firm with multiple segments

Busy director serving a firm with large R\&D expenditures

Busy director serving as an insider at own firm

Busy director with multiple committees

Busy director serving in multiple industries

\section{Control variables}

Log (CEO Directorships)

Industry director (\%)

Director ownership

Board interlock

CEO ownership

Log(board size)

Board committees

Independent director

(\%)

Log (sales)

Firm age

Growth opportunities

Business segments
The total number of directorships held by independent directors, divided by the number of independent directors

The proportion of directors serving on three or more boards, where at least one firm has assets above the sample median

The fraction of directors serving on three or more boards, where at least one firm has more business segments than the sample median

The fraction of directors serving on three or more boards, where at least one firm has R\&D expenditures above the sample median

The proportion of directors serving on three or more boards, when they also serve as an inside director on their company's board

The fraction of directors serving on three or more boards who also serve on more than four committees, which is the median number of committee appointments for an independent director

The fraction of directors serving on three or more boards, where at least two firms are in different Fama-French 48 industries

The natural logarithm of the number of directorships held by the CEO.

The percentage of busy directors with at least $50 \%$ of their directorships in the same Fama-French 48 industry code

Quintile measure of the combined board's voting control, excluding the CEO An indicator which takes the value of 1 if the firm's CEO sits on the board of one of the independent director's firms

The percentage of voting power that the CEO controls

The natural logarithm of the total number of directors on the firm's board

The number of board committees.

The percentage of independent directors on the board Log of total sales

The number of years the firm is in the CRSP database

Depreciation expense scaled by total sales

The number of business segments reported in COMPUSTAT 


\section{References}

Adams et al., 2005 R.B. Adams, H. Almeida, D. Ferreira. Powerful CEOs and their impact on corporate performance. Review of Financial Studies, 18 (2005), pp. 1403-1432.

Ahn et al., 2010 S. Ahn, P. Jiraporn, Y.S. Kim. Multiple directorships and acquirer returns. Journal of Banking and Finance, 34 (2010), pp. 2011-2026.

Beasley, 1996 M.S. Beasley. An empirical analysis of the relation between the board of director composition and financial statement fraud. The Accounting Review, 71 (1996), pp. 443-465.

Brickley et al., 1999 J.A. Brickley, J.S. Linck, J.L. Coles. What happens to CEOs after they retire? New evidence on career concerns, horizon problems, and CEO incentives. Journal of Financial Economics, 52 (1999), pp. 341-377.

Brookman and Thistle, 2011 Brookman, J., Thistle, P.D., 2011. Managerial compensation: Luck, skill or labor markets? Working Paper, Idaho State University.

Brown and Maloney, 1999 Brown, W., Maloney, M., 1999. Exit voice and the role of corporate directors: Evidence from acquisition performance. Working Paper, Clare McKenna College.

Coles and Li, 2011 Coles, J.L., Li, Z.F., 2011. Managerial attributes, incentives, and performance. Working Paper, Arizona State University.

Core et al., 1999 J.E. Core, R.W. Holthausen, D.F. Larcker. Corporate governance, chief executive officer compensation, and firm performance. Journal of Financial Economics, 51 (1999), pp. 371-406.

Cotter et al., 1997 J.F. Cotter, A. Shivdasani, M. Zenner. Do independent directors enhance target shareholder wealth during tender offers? Journal of Financial Economics, 43 (1997), pp. 195218.

Fama and Jensen, 1983 E.F. Fama, M.C. Jensen. Separation of ownership and control. Journal of Law and Economics, 26 (1983), pp. 301-325.

Ferris et al., 2003 S.P. Ferris, M. Jagannathan, A.C. Pritchard. Too busy to mind the business? Monitoring by directors with multiple board appointments. Journal of Finance, 58 (2003), pp. 1087-1112.

Fich and Shivdasani, 2006 E.M. Fich, A. Shivdasani. Are busy boards effective monitors? Journal of Finance, 61 (2006), pp. 689-724.

Gilson, 1990 S. Gilson. Bankruptcy, boards, banks, and blockholders. Journal of Financial Economics, 26 (1990), pp. 355-387.

Graham et al., 2012 J. Graham, S. Li, J. Qui. Managerial attributes and executive reputation. Review of Financial Studies, 25 (2012), pp. 144-186.

Guner et al., 2008 B.A. Guner, U. Malmendier, G. Tate. Financial expertise of directors. Journal of Financial Economics, 88 (2008), pp. 323-354.

Harford, 2003 J. Harford. Takeover bids and target directors' incentives: the impact of a bid on directors' wealth and board seats. Journal of Financial Economics, 69 (2003), pp. 51-53.

Jiraporn et al., 2008 P. Jiraporn, Y.S. Kim, W.N. Davidson III. Multiple directorships and corporate diversification. Journal of Empirical Finance, 15 (2008), pp. 418-435.

Jiraporn et al., 2009 P. Jiraporn, W. Davidson, P. DaDalt, Y. Ning. Too busy to show up? An analysis of directors' absences. Quarterly Review of Economics and Finance, 49 (2009), pp. 1159-1171.

Jiraporn et al., 2009 P. Jiraporn, M. Singh, C. Lee. Ineffective corporate governance. Director busyness and board committee memberships. Journal of Banking and Finance, 33 (2009), pp. 819-828. 
Lublin, 2012 J.S. Lublin. Are executives overboarded? Wall Street Journal (2012)

Samuels, 1993 M.L. Samuels. Simpson's paradox and related phenomena. Journal of the American Statistical Association, 88 (1993), pp. 81-88.

Scarsini and Spizzichino, 1999 M. Scarsini, F. Spizzichino. Simpson-type paradoxes, dependence, and ageing. Journal of Applied Probability, 36 (1999), pp. 119-131.

Shivdasani, 1993 A. Shivdasani. Board composition, ownership structure, and hostile takeovers. Journal of Accounting and Economics, 16 (1993), pp. 167-198.

Shivdasani and Yermack, 1999. A. Shivdasani, D. Yermack. CEO involvement in the selection of new board members: an empirical analysis. Journal of Finance, 79 (1999), pp. 1829-1853.

Wintoki et al., 2012 M.B. Wintoki, J.S. Linck, J.M. Netter. Endogeneity and the dynamics of internal corporate governance. Journal of Financial Economics, 105 (2012), pp. 581-606.

${ }^{1}$ See Wintoki et al. (2012) for a discussion of issues pertaining to endogeneity and the advantages and disadvantages of standard empirical approaches used in empirical governance analyses.

${ }^{2}$ The three boards cutoff is commonly used in the literature and is consistent with best-practice recommendations; for example, the National Association of Corporate Directors and the Council for Institutional Investors, both suggest that directors limit their board appointments.

${ }^{3} \mathrm{~A}$ detailed description of the data matching procedure and steps taken to clean the data is provided in Appendix A.

${ }^{4}$ In unreported tests we calculate the busyness measures for all directors and re-run our analysis. The results are qualitatively similar.

${ }^{5}$ These arguments are consistent with those of Jiraporn et al. (2009) who study busy directors and committee membership.

${ }^{6}$ The Tobin's Q calculation is also consistent with Coles et al. (2008), Guner et al. (2008), and Adams et al. (2005).

7This type of situation is known as a Simpson's Paradox, a detailed explanation of which can be found in Samuels, 1993, Scarsini and Spizzichino, 1999.

${ }^{8}$ We follow the suggestion of Jiraporn et al. (2009) and remove 2002 from the sample. We note that we receive qualitatively similar results when we include 2002.

${ }^{9}$ The use of firm fixed effects prevents us from using the earliest values for our measures of busyness.

${ }^{10}$ We note that we obtain similar results with these proxies as well.

${ }^{11}$ The variable name for whether a director is a nominating committee chair is different (nomchair in the legacy version and Nom_chair in the current version). Also, the indicator of whether a director owns less than $1 \%$ of voting power (ownless 1 ) is recorded as 1 or 0 in the legacy version and 'Yes' or 'No' in the current version of RiskMetrics.

${ }^{12}$ As for age, female, country_of_empl, dirsince, and classification, we correct 22, 64, 222, 52, and 10 director-firm-year observations, respectively. 